\title{
MODEL PEMBELAJARAN TWO-STAY TWO-STRAY BERBANTUAN GEOGEBRA TERHADAP KEMAMPUAN KONEKSI MATEMATIS
}

\author{
Riska Ayu Septianingrum ${ }^{1)}$, Eleonora Dwi Wahyuningsih ${ }^{2)}$, Wikan Budi Utami ${ }^{3)}$ \\ ${ }^{1223)}$ Program Studi Pendidikan Matematika, FKIP, Universitas Pancasakti Tegal, \\ Indonesia \\ riskaayu2996@gmail.com; eleonoradwi60@gmail.com ; wikan.piti@gmail.com
}

\begin{abstract}
The background of this research was based on students' lack of mathematical connection ability in learning. The aim of this research was to determine students' mathematical connection ability through Two-Stay Two-Stray learning model assisted by Geogebra application was better than that on cube and cuboid subject. The type of this research was Experimental and Design of Intact-Group Comparison Research. The sampling technique of this research used Cluster Random Sampling and students of grade VIII D, VIII E, VIII F in SMP Negeri 3 Slawi were chosen as the samples. The technique of collecting data used interview, documentation, and test. The result of this research showed that students' mathematical connection ability through Two-Stay TwoStray learning model assisted by Geogebra application was better than that without Geogebra application proven by the t-test.
\end{abstract}

Keywords : Efectivity,Two-Stay Two-Stray, Geogebra, Mathematical Connection Ability

\begin{abstract}
ABSTRAK
Latar belakang penelitian berdasarkan kemampuan koneksi matematis peserta didik yang masih kurang dalam pembelajaran. Tujuan penelitian adalah mengetahui kemampuan koneksi matematis peserta didik yang diajar menggunakan model pembelajaran Two-Stay Two-Stray berbantuan aplikasi Geogebra lebih baik daripada model pembelajaran Two-Stay Two-Stray pokok bahasan kubus dan balok. Jenis penelitian ini adalah Eksperimen dan Desain penelitian intact- Group Comparison. Sampel penelitian ini menggunakan teknik cluster Random Sampling dan terpilih kelas VIII D, VIII E, VIII F SMP Negeri 3 Slawi. Teknik pengumpulan data menggunakan wawancara, dokumentasi, dan tes. Hasil penelitian ini menunjukkan kemampuan koneksi matematis peserta didik yang diajar menggunakan model pembelajaran TwoStay Two-Stray berbantuan aplikasi Geogebra lebih baik daripada menggunakan model pembelajaran Two-Stay Two-Stray tanpa berbantuan aplikasi Geogebra dibuktikan dengan uji-t.
\end{abstract}

Kata Kunci : Efektivitas,Two-Stay Two-Stray, Geogebra, Kemampuan koneksi Matematis. 


\section{PENDAHULUAN}

Matematika merupakan salah satu mata pelajaran yang sudah diterapkan di setiap jenjang sekolahan dari mulai sekolah dasar, sekolah menengah, dan perguruan tinggi.Oleh karena itu matematika dikatakan sebagai ilmu yang dasar yang sangat berguna bagi kehidupan karena melalui matematika, siswa dapat dilatih untuk memiliki pemikiran yang kritis, sistematis, logis, kreatif dan kerjasama yang efektif.Tetapi masih banyak yang beranggapan bahwa matematika merupakan mata pelajaran yang terkesan abstrak bagi peserta didik sehingga sulit untuk dipahami.

Salah satu kesulitan yang
dialami peserta didik adalah
mengoneksikan keterkaitan antar
konsep. Berdasarkan kesulitan tersebut maka kemampuan koneksi matematis merupakan hal yang penting yang harus dimiliki oleh peserta didik.

Salah satu materi yang diajarkan dikelas VIII semester genap adalah materi bangun ruang sisi datar. Materi bangun ruang sisi datar bukan materi baru bagi peserta didik kelas VIII karena materi ini sudah pernah dipelajari pada saat sekolah dasar. Bangun ruang sisi datar diantaranya ada kubus dan balok. Kebanyakan peserta didik masih mengalami kesulitan untuk menyelesaikan masalah yang berkaitan dengan kubus dan balok. Salah satu kesulitan peserta didik dalam materi kubus dan balok adalah membayangkan suatu kubus dan balok yang berongga didalamnya sehingga peserta didik kurang dapat memahami bagian bagian dari kubus dan balok yaitu sisi, rusuk, titik sudut, diagonal sisi, diagonal ruang, dan bidang diagonal. Oleh karena itu, kemampuan koneksi matematis harus dimiliki dan dikembangkan pada peserta didik karena bangun ruang sisi datar materinya harus mampu mengaitkan berbagai konsep baik didalam matematika maupun diluar matematika. Hal ini yang mendasari pemilihan materi kubus dan balok sebagai materi yang akan diteliti.

Menurut Suherman dalam (Lestari, 2015) mengemukakan, bahwa kemampuan koneksi matematis adalah kemampuan mengaitkan konsep/ aturan matematika yang satu dengan yang lainnya, dengan bidang studi lain, atau dengan aplikasi pada dunia nyata. Kemampuan koneksi matematis dalam pembelajaran matematika sangat dibutuhkan. Dengan kemampuan koneksi matematis, peserta didik dapat menyelesaikan masalah- masalah yang berkaitan dengan matematika maka peserta didik akan mengenali dan menggunakan ide- ide matematika, memahami bagaimana ide- ide matematika saling terkoneksi dan menghubungkan menjadi satu kesatuan yang utuh, serta dapat mengenali dan menggunakan matematika dalam bidang lain dan kehidupan nyata. Sehingga konsep- konsep dalam matematika tidak terkesan abstrak dan lebih mudah dipahami oleh peserta didik.

Dalam proses pembelajaran matematika biasanya diperlukan media pembelajaran dengan tujuan untuk mempermudah guru dalam menyampaikan materi kepada peserta didik tanpa menggunakan bahasa- 
bahasa verbal yang sulit dipahami oleh peserta didik. Dimana media pembelajarannya harus disesuaikan dengan materi yang akan diajarkan. menurut Mahnun (2012) media merupakan sarana penyalur pesan atau informasi belajar yang hendak disampaikan oleh sumber pesan kepada sasaran atau penerima pesan tersebut. Salah satu media pembelajaran yang dapat menarik perhatian peserta didik dan memperjelas informasi adalah dengan menggunakan aplikasi geogebra.

Materi kubus dan balok adalah materi yang sangat memerlukan kemampuan koneksi matematis peserta didik tetapi guru masih belum menggunakan media pembelajaran pada saat pembelajaran berlangsung. Oleh karena itu , dalam penelitian ini media yang digunakan adalalah aplikasi geogebra. Dengan kelebihan yang dimiliki oleh aplikasi geogebra, diharapkan peserta didik mudah dalam memahami konsep materi yang disajikan oleh guru dan peserta didik menjadi lebih termotivasi untuk belajar. Selain itu, aplikasi geogebra dalam proses pembelajaran pada materi kubus dan balok akan lebih kongret. Aplikasi geogebra pada saat proses pembelajaran digunakan untuk memvisualisaikan bangun kubus dan balok sehingga peserta didik lebih mudah memahami konsep dan bagian- bagian dari kubus dan balok. Sehingga aplikasi geogebra juga dapat memberi kesan sehingga peserta didik akan lebih mudah untuk mengingat.

$$
\text { Menurut Agung (2018) }
$$
geogebra merupakan perangkat lunak komputer yang dapat memvisualisasikan objek- objek matematika secara tepat, akurat, dan efisien. Penelitian tentang aplikasi geogebra sebelumnya pernah diteliti oleh Aditama (2014) Efektivitas Pembelajaran induktif berbantuan geogebra pada materi garis singgung persekutuan dua lingkaran di kelas VIII SMP Negeri 1 Surabaya. Hasil penelitian menyatakan bahwa pembelajaran induktif berbantuan geogebra pada materi garis singgung persekutuan dua lingkaran dikelas VIII SMPN 1 Surabaya efektif.

Berdasarkan hal tersebut guru perlu memilih model pembelajaran yang tepat. Menurut Karli dan Yuliariatiningsih (Hamdani, 2011) menyatakan bahwa Metode pembelajaran kooperatif adalah suatu strategi belajar mengajar yang menekankan pada sikap atau perilaku bersama dalam bekerja atau membantu diantara sesama dalam struktur kerja sama yang teratur dalam kelompok, yang terdiri atas dua orang atau lebih. Dalam pembelajaran kooperatif diterapkan strategi belajar dengan sejumlah peserta didik sebagai anggota kelompok kecil yang mempunyai tingkat kemampuannya berbeda. Oleh karena itu berdasarkan kemampuan koneksi matematis peserta didik yang masih rendah dan peserta didik yang masih malu bertanya kepada guru pada saat proses pembelajaran berlangsung maka peneliti memilih model pembelajaran kooperatif salah satunya adalah model pembelajaran kooperatif Two-Stay Two-Stray berbantuan aplikasi geogebra. Menurut Lie (2007) 
Model pembelajaran Two-Stay TwoStray merupakan struktur dua tinggal dua tamu memberi kesempatan kelompok untuk membagikan hasil dan informasi dengan kelompok lain. Sehingga model pembelajaran TwoStay Two-Stray menuntut setiap kelompok mencari informasi dan memahami keterkaitan antara informasi yang telah dimiliki kelompoknya dengan informasi yang diperoleh dari kelompok lain, selanjutnya setiap kelompok mempertimbangkan jawaban manakah yang paling tepat. Pada proses pembelajaran peserta didik memiliki cara atau kemampuan mengoneksikan materi secara berbeda- beda, sehingga pada saat model pembelajaran berlangsung peserta didik dapat saling bertukar informasi kepada kelompok lain dan dapat menanyakan apa yang mereka belum dipahami tanpa merasa malu untuk bertanya kepada temannya sendiri sampai mereka benar- benar paham. Berdasrkan hal tersebut memungkinkan dapat meningkatkan kemampuan koneksi matematis peserta didik.

Beberapa keunggulan dari model pembelajaran Two-Stay TwoStray adalah unik dan menarik sehingga pada model pembelajaran ini semua peserta didik dituntut untuk berperan aktif dalam mengerjakan tugas. Dalam model pembelajaran Two-Stay TwoStray memungkinkan peserta didik untuk saling menstranfer ilmu antar peserta didik sehingga peserta didik menjadi lebih aktif baik dalam mencari pengetahuan, saling melengkapi materi, dan saling bertukar informasi sehingga pembelajarannya lebih bermakna dan mendorong siswa mengaitkan berbagai informasi untuk pengetahuannya sendiri. Dalam kegiatan kelompok dengan adanya bertukar informasi dan adanya perbedaan informasi yang diperoleh diharapkan peserta didik dapat mengoneksikan antara informasi yang sudah diperolehnya dengan informasi yang diperoleh dari kelompok lain sehingga peserta didik dapat memilih atau menerapkan konsep yang tepat dan sesuai. Dengan demikian penggunaan model pembelajaran TwoStay Two-Straymaka peserta didik akan lebih bersemangat dalam mengikuti pembelajaran yang berlangsung karena peserta didik bisa berdiskusi langsung dengan teman kelompok lainnya sehingga suasana kelas tidak menegangkan. Melalui model pembelajaran Two-Stay Two-Stray diharapkan dapat meningkatkan kemampuan koneksi matematis pada peserta didik.

Penelitian ini sebelumnya sudah pernah diteliti oleh Murniati, dkk (2015 didapatkan hasil bahwa hasil belajar siswa pada kelas yang menggunakan Pembelajaran kooperatif tipe Two-Stay Two-Stray (TSTS) lebih tinggi dibandingkan dengan kelas yang menggunakan pembelajaran konvesional (pembelajaran langsung).

Berdasarkan uraian tersebut, maka peneliti tertarik untuk melakukan penelitian untuk melihat efektivitas model pembelajaran two-stay two-stray berbantuan aplikasi geogebra terhadap kemampuan koneksi matematis pada materi bangun kubus dan balok.

\section{LANDASAN/KAJIAN TEORI}




\section{Efektivitas}

Menurut Hamdani (2011) cara untuk mengukur efektivitas adalah dengan menentukan transferbilitas (kemampuan memindahkan) prinsipprinsip yang dipelajari. Kalau tujuan dapat dicapai dalam waktu yang lebih singkat dengan strategi tertentu daripada strategi lain, strategi itu efisien. Kalau kemampuan mentransfer informasi atau skill yang dipelajari lebih besar dicapai melalui suatu strategi tertentu dibandingkan strategi lain, strategi tersebut lebih efektif utuk pencapaian tujuan.

Menurut Makmur

efektivitas merupakan dua kriteria yang biasa digunakan untuk menilai prestasi kerja dari suatu pusat pertanggung jawaban tertentu. Selain itu, menurut Sutikn (Makmur, 2015) mengemukakan bahwa pembelajaran efektif merupakan suatu pembelajaran yang memungkinkan siswa untuk dapatbelajar dengan mudah, menyenangkan, dan dapat mencapai tujuan sesuai dengan yang diharapkan.

Dengan demikian dapat dikatakan efektivitas adalah tingkat keberhasilan dalam mencapai tujuan pembelajaran setelah dilaksanakan proses belajar mengajar. Efektivitas dari penerepan model kooperatif tipe TwoStay Two-Stray berbantuan aplikasi geogebra dapat dilihat dari kemampuan koneksi matematis peserta didik yang lebih baik daripada menggunakan model pembelajaran Two-Stay TwoStray.

\section{Model Two-Stay Two-Stray}

Menurut Trianto (2010) model pembelajaran adalah suatu perencanaan yang digunakan sebagai pedoman guru dalam merencanakan suatu pembelajaran didalam kelas.Model pembelajaran Two-Stay Two-Stray merupakan model pembelajaran kooperatif yang memberikan kesempatan kepada kelompok untuk membagikan hasil dan informasi dengan kelompok lain (Lie,2007).

Model pembelajaran Two-Stay Two-Stray adalah model pembelajaran kooperatif yang memberikan kesempatan kepada peserta didik untuk saling mentransfer ilmu antar peserta didik dan menyampaikan informasi dan hasil kepada kelompok lain. Model pembelajaran Two-Stay Two-Stray juga sangat unik dan menarik untuk diterapkan dalam proses pembelajaran karena peserta didik diharapkan bisa saling tukar informasi dengan cara 2 anggota bertamu dan 2 angota tetap tinggal.

\section{Aplikasi Geogebra}

Menurut Oktaviani. dkk (2018) aplikasi geogebra merupakan salah satu alternatif media pembelajaran matematika yang memberikan pengalaman visual kepada peserta didik dalam berinteraksi dengan konsepkonsep geometri.

Selain itu, menurut Agung (2018) geogebra merupakan perangkat lunak komputer yang dapat menvisualisasikan objek- objek 
matematika secara tepat, akurat, dan efisien. Adapun keuntungan dalam menggunakan aplikasi geogebra dalam pembelajaran khususnya matematika adalah gambar yang dihasilkan lebih teliti dan akurat sehingga memberikan pengalaman visual bagi siswa dalam memahami konsep matematika.

Sehingga dapat disimpulkan bahwa aplikasi geogebra merupakan media pembelajaran yang digunakan untuk membantu gurudalam memvisualisasikan konsep- konsep matematika. Selain itu aplikasi geogebra juga merupakan alat bantu untuk menarik perhatian peserta didik dalam pembelajaran. Dengan aplikasi geogebra proses pembelajaran pada materi kubus dan balok akan lebih kongret. Peserta didik tidak hanya membayangkan bangun kubus dan balok, tetapi peserta didik juga dapat melihat secara langsung bangun kubus dan balok pada bagian titik sudut, rusuk, sisis, diagonal sisi, diagonal ruang, dan bidang diagonal. Sehingga aplikasi geogebra juga dapat memberi kesan sehingga peserta didik akan lebih mudah untuk mengingat.

Penelitian tentang aplikasi geogebra sebelumnya pernah diteliti oleh Aditama (2014) Efektivitas Pembelajaran induktif berbantuan geogebra pada materi garis singgung persekutuan dua lingkaran di kelas VIII SMP Negeri 1 Surabaya. Hasil penelitian menyatakan bahwa pembelajaran induktif berbantuan geogebra pada materi garis singgung persekutuan dua lingkaran dikelas VIII SMPN 1 Surabaya efektif.

\section{Kemampuan Koneksi Matematis}

Menurut Hendriana, Dkk (2017) koneksi matematis merupakan satu dari kemampuan matematis yang perlu dimiliki dan dikembangkan pada siswa sekolah menengah.

Menurut Lestari (2014) Kemampuan koneksi matematis merupakan salah satu kemampuan berfikir tingkat tinggi yang sangat penting dan harus dikembangkan karena dalam pembelajaran matematika setiap konsep berkaitan satu sama lain dengan konsep lainnya.

$$
\text { Dengan demikian dapat }
$$
disimpulkan bahwa koneksi matematis adalah kemampuan peserta didik dalam menerapkan suatu konsep dengan konsep yang lainnya.Selain itu kemampuan koneksi matematis pada peserta didik sangat diperlukan untuk mempermudah dan memperdalam peserta didik dalam memahami materi pelajaran matematika. Sehingga koneksi matematis yang baik akan memberi peluang berlangsungnya belajar matematika secara bermakna, maka peserta didik tidak hanya hapal atau mengingat konsep dalam jangka pendek namun penguasaan konsepnya lebih tahan lama.

\section{METODE PENELITIAN}

\section{Jenis Penelitian}

Jenis Penelitian ini adalah eksperimen dengan pendekatankuantitatif dan desain penelitian yang digunakan adalah desain intact- Group Comparison. 


\section{Waktu dan Tempat Penelitian}

Penelitian dilakukan pada tanggal 18 Maret 2019 sampai dengan tanggal 20 April 2019 selama 6 kali pertemuan dengan pokok bahsan kubus dan balok di SMP Negeri 3 Slawi tahun Ajaran 2018/2019.

\section{Subjek Penelitian}

Populasi penelitian ini adalah peserta didik kelas VIII Semester II SMP Negeri 3 Slawi Tahun Ajaran 2018/2019 yang terdiri terdiri atas 10 kelas yang berjumlah 314 peserta didik. Teknik pengambilan sampel penelitian ini adalah Cluster Random Sampling, dari 10 kelas dipilih tiga kelas untuk dijadikan sampel, yaitu kelas VIII D (Kelas eksperimen I), Kelas VIII E (Kelas uji coba), Kelas VIII F ( Kelas eksperimen II).

\section{Prosedur Penelitian}

Model pembelajaran Two-Stay Two-Stray berbantuan aplikasi Geogebra dilakukan pada pokok bahasan kubus dan balok. Model pembelajaran Two-Stay Two-Stray berbantuan aplikasi Geogebra dilakukan untuk mengetahui kemampuan koneksi matematis pada peserta didik. Selain itu Model pembelajaran Two-Stay TwoStray berbantuan aplikasi Geogebra digunakan untuk memperjelas peserta didik dalam memahami konsep pada materi kubus dan balok. Pada akhir penelitian peserta didik diminta mengisi tes essaykemampuan koneksi matematis untuk mengetahui hasil kemampuan koneksi matematis pada peserta didik.

\section{Instrumen Penelitian}

Instrumen yang digunakan penelitian ini adalah instrumen tes. Instrumen tes yang digunakan adalah tes kemampuan koneksi matematis peserta didik tertulis yang berbentuk soal essay sebanyak 6 soal. Hasil analisis butir soal menggunakan uji validitas tes, uji reliabilitas tes, uji tingkat kesukaran soal, dan uji daya beda soal.

Uji validitas tes didefinisikan sebagai ukuran seberapa cermat suatu alat ukur melakukan fungsi ukur (Utami, 2014). Untuk mengetahui validitas tiap butir tes essay atau uraian dapat menggunakan penghitungan koefisien korelasi product moment atau $\mathrm{r}$ pearson, Hasil perhitungan dengan $\alpha=$ $5 \%$ dan $\mathrm{n}=32$ diperoleh rtabel $=0,349$. Dari 10 butir soal yang diuji cobakan ada 8 soal yang valid dan 2 soal tidak valid. 8 soal yang valid yaitu soal nomor 1, 2, 4, 5, 7, 8, 9, 10. Sedangkan butir soal yang tidak valid yaitu soal nomor 3 dan 6.Uji Reliabilitas suatu instrumen adalah keajegan instrumen tersebut apabila diberikan pada subjek yang sama meskipun oleh orang yang berbeda. Adapun untuk menguji reliabilitas tes uraian menggunakan rumus KR-20, Berdasarkan hasil perhitungan mengunakan analisis uji r_xx diperoleh r_xx $=0,6805$. Kemudian dikonsultasikan dengan tabel distribusi r_tabel $=0,349$. Karena $r_{-} \mathrm{xx}$ $>$ r_tabel maka tes tersebut reliabel dengan Interpretasi Reliabilitas Sedang. Sehingga soal yang dipakai ada 6 soal yaitu soal nomor 1, 5, 7, 8, 9, dan 10 . 


\section{Teknik Pengumpulan Data}

Teknik pengumpulan data
penelitian ini menggunakan teknik
wawancara, dokumentasi, dan tes .
Wawancara digunakan untuk
mendapatkan informasi tentang proses pembelajaran matematika, dan kemampuan koneksi matematis peserta didik kelas VIII SMP Negeri 3 Slawi, untuk mengetahui data kondisi awal peserta didik. Dokumentasi digunakan untuk mendapatkan data- data peserta didik. Tes digunakan untuk mencari data kemampuan koneksi matematis peserta didik.

Data yang digunakan penelitian ini adalah hasil akhir dari tes kemampuan koneksi matematis yang meliputi beberapa Indikator kemampuan koneksi matematis pada penelitian ini bersumber pada kegiatan pembelajaran peserta didik disekolah menurut Sumarmo (Lestari, 2015) yang terdiri dari 6 indikator. Namun dalam penelitian ini dibatasi dengan 3 yaitu : (1) mencari hubungan berbagai representasi konsep dan prosedur. (2) memahami hubungan diantara topik matematika. (3) mencari hubungan satu prosedur dengan prosedur lain dalam representasi yang ekuivalen.

\section{Teknik Analisis Data}

Teknis analisis data penelitian ini dalam pengujian hipotesis menggunakan uji-t satu pihak kanan. Dengan terlebih dahulu data diuji menggunakan uji Lillierfors dan Bartlett untuk mengetahui normalitas dan homogenitas data.

\section{HASIL DAN PEMBAHASSAN}

\section{Hasil Penelitian}

Penelitian ini dilaksanakan di SMP Negeri 3 Slawi dengan tujuan untuk mengetahui kemampuan koneksi matematis peserta didik yang diajar menggunakan model pembelajaran Two-Stay Two-Stray berbantuan aplikasi Geogebra lebih baik daripada model pembelajaran Two-Stay TwoStray. Data penelitian ini diperoleh dari hasil uji hipotesis dan pembahasan hasil penelitian.

Sebelum pemberian perlakuan kepada kelas eksperimen I dan eksperimen II, dilakukan uji prasyarat sebelum penelitian yang meliputi uji normalitas, uji homogenitas, dan uji kesetaraan sampel. Data yang digunakan adalah nilai Penilaian Akhir Semester Gasal Tahun Ajaran 2018/2019. Hasil analisis menyatakan bahwa tidak ada perbedaan antara kelas eksperimen I, kelas eksperimen II, dan kelas uji coba (sampel setara).

Data kemampuan koneksi matematis diperoleh dari nilai tes berbentuk essay yang berjumlah 6 soal pokok bahasan kubus dan balok. Tes ini diberikan kepada peserta didik kelas VIII SMP Negeri 3 Slawi yang terpilih sebagai kelas eksperimen I dan eksperimen II. Hasil perhitungan dapat dilihat pada tabel 1 . 


\section{Tabel 1.Hasil Analisis Perhitungan Tes Kemampuan Koneksi Matematis} Dengan Uji t Satu Pihak Kanan

\begin{tabular}{ccccc}
\hline No & Variabel & $\mathrm{t}_{\text {hitung }}$ & $\mathrm{t}_{\text {tabel }}$ & Kesimpulan \\
\hline 1. & Kemampuan & 2,052 & 1,670 & $\mathrm{H}_{0}$ Ditolak
\end{tabular}

koneksi matematis

Berdasarkan hasil perhitungan menggunakan analisis uji $\mathrm{t}$ satu pihak kanan untuk kemampuan koneksi matematis diperoleh thitung $=2,052$ dan ttabel $=1,670$ dengan taraf signifikansi $5 \%$. Karena thitung $>$ ttabel maka H0 ditolak sehingga dapat dikatakan model pembelajaran TwoStay Two-Stray berbantuan aplikasi Geogebra lebih baik daripada model pembelajaran Two-Stay Two-Stray terhadap kemampuan koneksi matematis.

\section{Pembahasan}

Berdasarkan hasil penelitian kemampuan koneksi matematis yang diajar menggunakan model pembelajaran Two-Stay Two-Stray berbantuan aplikasi Geogebra lebih baik daripada model pembelajaran TwoStay Two-Stray. Hal ini sependapat dengan Lie (2007) Model pembelajaran Two-Stay Two-Stray merupakan struktur dua tinggal dua tamu memberi kesempatan kelompok untuk membagikan hasil dan informasi dengan kelompok lain. Sehingga kemampuan koneksi peserta didik dapat meningkat dengan saling bertukarnya informasi dari kelompok lain. Selain itu, diperkuat juga dengan Agung (2018) geogebra merupakan perangkat lunak komputer yang dapat menvisualisasikan objek- objek matematika secara tepat, akurat, dan efisien. Dengan demikian peserta didik akan lebih mudah dalam memahami konsep pada materi pembelajaran khususnya kubus dan balok. Hal ini diperkuat oleh penelitian oleh Aditama (2014) Efektivitas Pembelajaran induktif berbantuan geogebra pada materi garis singgung persekutuan dua lingkaran di kelas VIII SMP Negeri 1 Surabaya. Hasil penelitian menyatakan bahwa pembelajaran induktif berbantuan geogebra pada materi garis singgung persekutuan dua lingkaran dikelas VIII SMPN 1 Surabaya efektif.

Pembelajaran dikelas eksperimen 1 menggunakan model pembelajaran Two-Stay Two-Stray berbantuan aplikasi geogebra. pelaksanaan pembelajaran dimulai dengan menyampaikan tujuan pembelajaran yang akan dicapai peserta didik dan menyiapkan tugas peserta didik serta memberikan motivasi untuk mengikuti proses pembelajaran dikelas. Kemudian guru membagi peserta didik menjadi beberapa kelompok yang terdiri dari 4 peserta didik. Selanjutnya guru mepresentasikan materi pembelajaran dengan berbantuan aplikasi geogebra, dengan aplikasi geogebra peserta didik lebih tertarik dan bisa lebih mudah memahami materi karena peserta didik bisa melihat secara nyata bangun kubus dan balok. Sehingga kemampuan mengoneksikan materi lebih baik.

Setelah guru mempresentasikan materi pembelajaran guru memberikan tugas atau soal- soal kepada masingmasing kelompok yang nantinya 
didiskusikan bersama kelompoknya sendiri atau kelompok lain dari apa yang mereka pahami. Sehingga pada saat proses pengelompokan mereka saling bertukar informasi atau bertukar ilmu kepada kelompok lain dan peserta didik dimerasa malu untuk bertanya kepada temannya sendiri sampai mereka dapat memahami materi dan menemukan jawaban yang tepat. Selanjutnya salah satu dari kelompok maju mempresentasikan hasil diskusiannya di depan kelas kemudian guru membahas dan mengarahkan siswa ke bentuk formal.

Penelitian yang telah dilakukan dengan menggunakan model pembelajaran Two-Stay Two-Stray berbantuan aplikasi Geogebra membuat peserta didik dapat menemukan konsep secara mandiri sehingga pada saat model pembelajaran dilaksanakan peserta didik saling bertukar informasi atau bertukar ilmu kepada kelompoknya sendiri atau kelompok lain. Dalam proses kelompok peserta didik dapat menemukan jawaban sendiri yang tepat sehingga kemampuan mengoneksikan semakin baik dari yang didapat kelompok sendiri atau kelompok lain, maka peserta didik diberikan soal latihan untuk memperdalam ingatan terhadap suatu konsep yang telah diperoleh

\section{SIMPULAN DAN SARAN Simpulan}

Berdasarkan hasil penelitian
yang diperoleh setelah melakukan penelitian terhadap masalah yang telah dikemukakan dapat diampil kesimpulan bahwa kemampuan koneksi matematis yang diajar menggunakan model pembelajaran Two-Stay Two-Stray berbantuan aplikasi Geogebra lebih baik daripada model pembelajaran Two-Stay Two-Stray..

\section{Saran}

Dalam proses pembelajaran hendaknya guru dapat memilih model pembelajaran yang tepat disesuaikan dengan kondisi peserta didik dan guru juga dapat memilih media pembelajaran yang tepat sesuai materi yang akan diajarkan agar peserta didik dapat memahami konsep tidak hanya menghafal tetapi akan lebih lama diingat oleh peserta didik. Dengan demikian pemahaman peserta didik dalam kemampuan mengoneksikan materi pelajaran lebih meningkat.

\section{DAFTAR PUSTAKA}

Aditama, F. (2014).Efektivitas pembelajaran induktif berbantuan geogebra pada materi garis singgung persekutuan dua lingkaran di kelas VIII SMP Negeri

Surabaya. MATHEdunesa, 3(3).

Agung, S. (2018).Pemanfaatan Aplikasi Geogebra dalam Pembelajaran Matematika SMP. Prosiding, 3(1). Hendriana, Heris dan Rohaeti, E.E dan Sumarmo, Utari. (2017). Hard Skills dan Soft Skills Matematik Siswa. Bandung. Refika Aditama. Lestari, K. E. (2014). Implementasi Brain-Based Learning untuk meningkatkan kemampuan koneksi dan kemampuan berpikir kritis serta motivasi belajar siswa SMP. Judika (Jurnal Pendidikan Matematika). 2(1).

Lie, A. (2007). Cooperative Learning: Mempraktikkan Cooperative Learning di Ruang-ruang Kelas. 
Jakarta: Grasindo.

Mahnun, N. (2012). Media Pembelajaran (Kajian terhadap Langkah-langkah Pemilihan Media dan Implementasinya dalam

Pembelajaran). ANIDA', 37(1), 27-34.

Makmur, A., \& Aspia, A. (2015). Efektifitas Penggunaan Metode Base Method dalam Meningkatkan Kreatifitas dan Motivasi Belajar Matematika Siswa SMP Negeri 10 Padangsidempuan. EduTech: Jurnal Ilmu Pendidikan dan Ilmu Sosial. Jurnal Mahasiswa FKIP Universitas Pasir Pengiran. 1(1).

Murniati, Y., Deswita, H., dan Arcat. (2015). Pengaruh Model Pembelajaran Kooperatife Tipe Two Stay Two Stray (TSTS) terhadap Hasil Belajar
Matematika Siswa Kelas VII MTS Thamrin Yahya Rambah Hilir. 1(1)

Oktaviani, D. N., Sholikhakh, R. A., \& Lestiana, H. T. (2018). Pendampingan Penggunaan Geogebra Untuk Guru Matematika SMP/MTS Se Kecamatan Talang Kabupaten Tegal. JPPM (Jurnal Pengabdian dan Pemberdayaan Masyarakat), 2(1), 153-156.

Trianto. (2010). Model Pembelajran Terpadu, Konsep, strategi dan Implementasinya dalam KTSP. Jakarta: Rineka Cipta.

Utami, W. B. (2014). Pengaruh Prestasi Di Slta, Motivasi Mahasiswa Dan Kualitas Mengajar Dosen Terhadap Indeks Prestasi Mahasiswa Di Stie Aas Surakarta. Jurnal Akuntansi dan Pajak, 15(01). 
